\title{
Combating Human Trafficking in the Southern African Development Community: Strategies, Challenges, and Opportunities
}

\section{Clayton Hazvinei Vhumbunu}

Public Service Accountability Monitor

Rhodes University, South Africa
Article DOI:

https://doi.org/10.35293/srsa.v42i2.79

\section{Abstract}

As is the case the world over, human trafficking remains a serious issue of concern amongst the Southern African Development Community (SADC) member states. At a time when most of the SADC states are confronted with slow economic growth, poverty and limited economic opportunities, several people continue to be forcibly or deceptively recruited and transported across borders for various purposes that include sexual exploitation, forced labour, slavery and/or removal of organs. This is despite the fact that most SADC countries are signatories to the United Nations Protocol to Prevent, Suppress and Punish Trafficking in Persons of 2000, especially Women and Children (the Palermo Protocol) which supplement the United Nations Convention against Transnational Organized Crime (UNTOC). However, SADC member states have been implementing a sundry of strategies in the form of policies, legislations, regional interventions and plans of action such as the 10 Year SADC Strategic Plan of Action on Combating Trafficking in Persons, especially Women and Children (2009-2019), in order to combat human trafficking in the region. With the use of primary and secondary data sources, this paper sought to evaluate the anti-trafficking strategies that have been implemented so far by SADC member states at national and regional level. It further identifies the challenges being encountered, as well as opportunities presented within the regional and global networks for fighting human trafficking. On the strength of the research findings, appropriate suggestions are made to enhance the success of strategies being implemented in the SADC region in particular, and other parts of Africa in general.

Keywords: human; trafficking; SADC; anti-trafficking; exploitation. 


\section{Introduction}

Despite the existence of several legislative, institutional and policy measures put in place to combat human trafficking by the Southern African Development Community (SADC) member states at sub-national, national and regional level; the heinous crime and phenomenon continue to constitute a thriving industry. Although official and updated statistics on human trafficking are absent, cases and incidents of trafficking in persons are awash in the media and several others pass unreported every day. What is more disturbing is the grim and devastating fact that trafficking in persons certainly pose a serious threat to regional security, regional integration, regional development and socio-economic status of citizens in the region. This has also been the case with SADC. Whilst several studies have resorted to examining the causes and consequences of human trafficking, as well as approaches employed to address human trafficking across the globe, it may be time to critically assess the efficacy of strategies, laws, institutions and policies that have been formulated at regional and national level in SADC to combat human trafficking as well as attendant challenges faced, and opportunities presented, in the fight against the psycho-socially traumatic and dehumanizing practice. The first section will define and present the methodology and conceptual discussion that underpin the analysis. The second section presents an overview of antihuman trafficking interventions being attempted through regional integration arrangements in Africa and beyond. The strategies, policies, laws and institutions for combating human trafficking in SADC are then examined in the third section before assessing the successes, challenges and complexities in implementing antihuman trafficking strategies in Southern Africa. Recommendations are outlined as a way forward in the last section before concluding remarks.

\section{Contextualizing Human Trafficking: Africa and the World}

Human civilization the world over gave rise to migration as people cross local, national and international borders in in light push factors and pull factors, be they economic, social, political and security-related. The rise of security threats and the need to protect national interests in terms of labour markets, health management and disease control, managing criminality, et cetera has witnessed the tightening of visa regimes to regulate the flow of migrants into national 
territories. With most migrants in less developed countries motivated by pull factors, mostly in search of economic opportunities in more developed countries, and some driven by push factors in the form of conflicts, droughts and instability; the migrants-receiving countries are slowly making their visa application and requirement processes more stringent as they use visas as an instrument to advance their foreign policy and domestic policy. In most cases, visa applicants or migrants at ports of entry are requested to meet set criteria for short-term stay visas, visitor's visas, long-stay visas, migrant visas, business visas, study visas, asylum or refugee seekers.

Whereas mobility continues to generally increase in terms of global migration, for citizens in developing countries there has been a challenge as most of them incessantly struggle to satisfy immigration rules and regulations. As Mau et al. (2015) noted, whilst citizens of industrialized and developed countries have gained mobility rights with more freedom of movement, the mobility rights of those citizens from poor, politically and economically fragile developing countries in the Global South, in particular from Africa, have stagnated and even diminished. In the end, this has been embraced by entrepreneurs who are now taking advantage of desperate and vulnerable people by posing as 'travel agents', 'travel consultants' 'employers' or 'facilitators' who make false promises, deceive victims or even use force to traffick and trade them for forced labour, commercial sex work, sex slaves, organ removal, forced military services/armed combatants in wars and other purposes. The International Organization for Migration (IOM)'s Human Trafficking Global Database reveals that whilst the main forms of human trafficking are trafficking for sexual exploitation, sexual slavery, forced marriage, armed conscription, and forced labour; the most common form of human trafficking in the world since 2005 to the present is forced labour, followed by sexual exploitation.

Very cunning human traffickers are employing various creative and deceptive confidence tricks to lure their human trafficking victims across the globe with sophistry. The United Nations Office on Drugs and Crime (UNODC) Global Report on Trafficking in Persons for 2018 confirmed that human trafficking victims are on the rise, with armed groups and terrorists increasingly trafficking women and children to generate funds for their terrorist activities. Between 2003 and 2019, the UNODC has collected information about 225000 victims of human trafficking detected across the world (UNODC 2019). The report, which 
covers 142 countries worldwide, reported that trafficked children now account for 30 percent of all detected victims with more girls than boys being trafficked whilst sexual exploitation emerging as the main purpose of human trafficking, accounting for 59 percent (UNODC 2018). Most victims of trafficking for sexual exploitation are detected in Europe, the Americas, East Asia and the Pacific whereas trafficking for forced labour is commonly detected in Africa, especially in conflict zones and refugee camps through abduction, with several cases reported in Central and West Africa (UNODC 2018). The same report notes that richest countries are destinations for long distance flows of human trafficking, with Western Europe, Southern Europe and Middle East countries recording a sizeable share of human trafficking victims (UNODC 2018). This is why the Sustainable Development Goal (SDG) 8 on Decent Work and Economic Growth, specifically SDG target 8.7 which aims at taking immediate and effective measures to eradicate human trafficking as well as forced labour, child labour, morden slavery and the recruitment of children as soldiers (United Nations 2020). In Africa, people are mostly trafficked for forced labour and sexual exploitation. In Southern Africa, specifically, the UNODC Global Report on Trafficking in Persons for 2018 reported that of detected trafficking victims, 83 percent of them were trafficked for forced labour whilst 17 percent were trafficked for sexual exploitation.

Whilst a lot of efforts are being put at national level to combat human trafficking through the enactment of laws, national strategies and policies; most Regional Economic Communities (RECs) in Africa have been implementing various strategies and pursuing different action plans to address the same. The Economic Community for West African States (ECOWAS) had the ECOWAS Plan of Action against Trafficking in Persons (2002-2003), ECOWAS Plan of Action against Trafficking in Persons (2006-2009), ECOWAS Policy on Protection and Assistance to Victims of Human Trafficking, and the ECOWAS Strategic Plan of Action for the Combat of Trafficking in Persons in West Africa (2010-2013) which is currently under review (ECOWAS 2019). In East African Community (EAC), the EAC Anti-Trafficking in Persons Act was enacted, whilst in the Economic Community for Central African States (ECCAS) they have in place the Joint ECCAS/ECOWAS Plan of Action against Trafficking in Persons in West and Central Africa (2006), the ECCAS Human Trafficking Protocol and the Horn of Africa Initiative on Human Trafficking and Migrant Smuggling covering most 
member states of the Inter-Governmental Authority on Development (IGAD). Other regional organizations also have more or less similar strategies although the state, pace and level of implementation of these strategies always vary. All these are guided by continental initiatives such as the African Union Commission Initiative against Trafficking (AU COMMIT) adopted in 2009 to consolidate the African Union's efforts to combat human trafficking.

Given the nature of human trafficking, being a cross border crime, most countries have realized that regional approaches and cooperation in prevention, detection and prosecution of human traffickers are critical in complementing national-level interventions in ensuring long lasting solutions to the scourge. Although such approaches have proven to be more effective, it is always essential to constantly review the efficacy and potency of such regional strategies in addressing human trafficking in order to draw lessons for other regions as well as identify challenges and opportunities that can be instructive in strengthening efforts against human trafficking.

\section{Analytical Approach}

It may be necessary and needy to map the terrain surrounding human trafficking as a field of study and practice in order to facilitate conceptual clarity and useful analysis. Most theoretical concepts describing human trafficking have tended to focus on the aims and/or causes of human trafficking (Anderson and Davidson 2003). The concepts of human trafficking and regional integration constitute the conceptual framework of analysis for this research.

Being a multi-faced phenomenon that it is, human trafficking has attracted multi-perspective dimensions in terms of analysis ranging. Some scholars have adopted the human rights perspective in human trafficking (see for instance Abdullah 2019; Kaye et al 2019; Vanwesenbeeck 2019; Wade 2020) whilst others have analysed human trafficking from the perspective of trans-organized crime (see Jesperson et al. 2019; Markovic et al. 2019; Skilbrei 2019; Farell et al. 2019). A number of scholars have also maintained health perspectives to human trafficking (see for instance Murray and Smith 2019; Stevens et al. 2019; Sinha et al. 2019; Fang et al. 2019; Costa el al. 2019; Sutherland 2019).

In terms of definition, human trafficking can generally be defined as the trade in humans through the use of violence, force, fraud, manipulation, deception, 
false promises, coercion or any improper means for the purposes of sexual exploitation, forced labour, forced begging, domestic servitude, forced criminality, forced marriage, forced organ removal, debt bondage, and any other purposes.

A more comprehensive definition of human trafficking is provided under Article 3 (a) in the UN Protocol to Prevent, Supress and Punish Trafficking in Persons, especially Women and Children of 2000 (also referred to as the Trafficking Protocol or UN TIP Protocol):

"Trafficking in Persons as the recruitment, transportation, transfer, harbouring or receipt of persons, by means of the threat or use of force or other forms of coercion, of abduction, of fraud, of deception, of the abuse of power or of a position of vulnerability or of the giving or receiving of payments or benefits to achieve the consent of a person having control over another person, for the purpose of exploitation. Exploitation shall include, at a minimum, the exploitation of the prostitution of others or other forms of sexual exploitation, forced labour or services, slavery or practices similar to slavery, or the removal of organs".

Almost similarly, the SADC Protocol on Gender and Development of 2008 presents a definition of human trafficking as follows;

" $[\mathrm{H}]$ uman trafficking means the recruitment, transportation, transfer, harbouring or receipt of persons, by means of the threat, abuse of power, position of vulnerability, force or other forms of coercion, abduction, fraud or deception to achieve the consent of a person having control over another person for the purpose of amongst other things, sexual and financial exploitation" (SADC 2008:8).

Thus, victims of human trafficking are usually susceptible given their economic hardships, natural disasters, political instability, displacement, emotional vulnerability, lack of social support, family breakdown, among other forms of vulnerabilities. The major elements of human trafficking, as presented in Figure 1 below, revolves around the act, means/techniques and purpose of human trafficking. This may also assist to address the conceptual confusion, conceptual inconsistences and erroneous conceptual conflation that oftentimes befell scholars and policymakers when they attempt to distinguish human trafficking from 'human smuggling' or 'migrant smuggling,' which is defined by 
Article 3 (a) of the UN Protocol against the Smuggling of Migrants by Land, Sea and Air of 2000 as "the procurement, in order to obtain, directly or indirectly, a financial or other material benefit, of the illegal entry of a person into a State Party of which the person is not a national or permanent resident”.

Thus, the dichotomy of coercion and consent distinguish the former from the latter as there is no element of deception, exploitation or coercion in human smuggling but there is free will and victims are free to make their choices once they make their payment upon crossing the border. Therefore, the act, means and purpose of human trafficking assist to differentiate it from human smuggling, with the latter mainly involving human beings crossing cross-border, which is not always the case with human trafficking.

Figure 1: Elements of Human Trafficking

\begin{tabular}{|l|l|l|l|}
\hline \begin{tabular}{|l|l|} 
ACT \\
Recruitment \\
Transport \\
Transfer \\
Harbouring \\
Receipt of Persons
\end{tabular} & \begin{tabular}{|l|l|l|} 
MEANS \\
Threat or use of \\
force \\
Coercion or \\
abduction \\
Fraud \\
Deception \\
Abuse of power or \\
vulnerability or \\
Giving payments or \\
benefits
\end{tabular} & $\begin{array}{l}\text { PURPOSE } \\
\text { Exploitation } \\
\text { including } \\
\text { Prostitution of } \\
\text { others } \\
\text { Sexual exploitation } \\
\text { Forced labour } \\
\text { Slavery or similar } \\
\text { practices } \\
\text { Removal of organs } \\
\text { Other types of } \\
\text { exploitation }\end{array}$ \\
\hline
\end{tabular}

Source: UNODC (2020).

In terms of typology, several authors have identified trafficking for sexual exploitation, trafficking for forced labour, trafficking for sexual slavery, trafficking for forced marriage, trafficking for army conscription, and trafficking for organ removal as the main and common forms of trafficking (see for instance BuschArmendariz et al. 2009; Murray and Smith 2019; Smith and Kangaspunta 2012; Winterdyk 2020). Authors such as Winterdyk (2020) have considered human trafficking as "modern-day slavery" or "neo-slavery" given the involuntary servitude and magnitude of human violations imposed by human trafficking as well as the slave-like circumstances, violence and intimidation that characterize human trafficking yet victims do not get anything of material or non-material value in the process. Given the act, means, purpose, actors, players and nature 
of human trafficking, complementing national approaches with regional approaches has the potential to secure more comprehensive solutions to the phenomenon.

Regional approaches to combating crimes that have a regional dimension are facilitated through regional integration. The African Development Bank (2019) comprehensively define regional integration as "an agglomeration of Member States that cluster on the basis of agreed policies, legal/regulatory frameworks and institutional arrangements to pursue and implement, within defined territory/territories, common, joint, coordinated or harmonized policies, projects and programmes in simultaneous, sequential or phased manner". Thus, it is about having sovereign states establishing common economic, political, legal and social institutions of collective governance. Most regional organizations in Africa, and even beyond, have now appreciated the need and urgency for expanding areas of cooperation as they move away from the narrow traditional conceptualization of regional integration as a tool of trade and economic cooperation, to a broader conceptualization of regional integration as an instrument that can foster cooperation in all policy domains including fighting crime.

Several scholars have underscored the effectiveness of such an approach, arguing that collaborative efforts in preventing and combating crime can best deliver if there are complementary and mutually re-enforcing interventions at national, sub-regional, regional and global levels (see Gordon 2009; Ewi and Aning 2006; Masabo et al. 2014; McKenzie 2019). Such approaches, which are invaluable in strengthening regional partnerships, complementarities, capacities, burden-sharing as well as facilitating inter-jurisdictional and crossborder coordination; are encouraged by the United Nations Convention against Transnational Organized Crime (see Article 7, Article 27, and Article 28 of the UNTOC). However, whilst regional approaches in fighting crime are commended and recommended, several challenges always confront regional organizations in the process. To Masabo et al. (2014), inadequate resources; reluctance by member states to sign, ratify and domestic supporting institutional framework (treaties, conventions, and protocols) and lack of advanced technology to combat morden day crime. In addition, the absence of effective sanctionary frameworks in regional organizations to punish member states that fail to implement agreed decisions, treaty provisions, protocols, strategies and policies remains Achilles' heel and weakest link of regional bodies as states usually resort to persuasion, diplomatic 
engagement and other forms of lobbying and advocacy to solicit compliance.

In terms of methodology, this research makes use of primary and secondary data sources for analysis. Mostly, the official reports from SADC, SADC member states, and other various forms of literature are consulted.

\section{Strategies, Policies, Laws and Institutions for Combating Human Trafficking in SADC}

As of 3 March 2020, all SADC member states have either ratified or acceded to the UNTOC, and the Protocol to Prevent, Suppress and Punish Trafficking in Persons, especially Women and Children (see UN Treaty Collections 2020). They are also party to several human trafficking related conventions such as the Convention on the Elimination of All Forms of Discrimination against Women (CEDAW) of 1979, Convention on the Rights of the Child (CRC) of 1989, International Labour Organization Convention on Forced Labour No. 29 of 1930, International Labour Organization Convention on the Abolition of Forced Labour No. 105 of 1957, and the International Labour Organization Convention on the Prohibition and Immediate Action for the Elimination of the Worst Forms of Child Labour of No. 182 of 1999.

Other than international instruments put in place at the UN level, there are continental initiatives that guide SADC member states to combat human trafficking. These include the Constitutive Act of the African Union of 2000, The Ouagadougou Action Plan to Combat Trafficking in Human Beings, Especially Women and Children of 2006; The African Charter on Human and Peoples Rights of 1981 and its Protocol relating to the Rights of Women of 2002; The African Charter on the Rights and Welfare of the Child of 1990; The African Common Position on Children (Declaration and Plan of Action of 2001); The African Common Position on Migration and Development of 2006, The Migration Policy Framework for Africa (MPFA 2018-2030) and the Joint AU-EU Declaration on Migration and Development of 2006. All of these underscore the significance of enhancing collaborative integrated approaches and mechanisms for co-operation at the community, sub-national, national and regional level in the battle against human trafficking, with an emphasis on Regional Action Plans. In addition to this, the African Union is finalizing its Ten-Year Action Plan on Eradication of Child Labour, Forced Labour, Morden Slavery and Human 
Trafficking in Africa (2018-2030).

Within SADC, SADC member states have been implementing a sundry of strategies in the form of policies, legislations, regional interventions and plans of action in order to combat human trafficking in the region. These include 10 Year SADC Strategic Plan of Action on Combating Trafficking in Persons, especially Women and Children (2009-2019), which is a blueprint for guiding comprehensive regional and national responses to human trafficking since 2009. The 10 Year SADC Strategic Plan of Action on Combating Trafficking in Persons identified eight strategic priority areas of focus and action in combating human trafficking. These are legislative and policy measures, training for skills enhancement and capacity building, prevention and public awareness raising, victim support and witness protection, coordination and regional cooperation, research and information sharing, monitoring and evaluation, and resource mobilization (SADC 2009:11-15).

Following the mid-term review of the 10 Year SADC Strategic Plan of Action on Combating Trafficking in Persons (2009-2019) in 2016, there was a strategic refocusing of the Strategic Plan of Action's priorities for the remaining implementation period of 2016 to 2019. Therefore, the Revised Strategic Plan of Action on Combating Trafficking in Persons, especially Women and Children (2016-2019) was also developed and approved by the SADC Ministerial Committee of the Organ on Politics, Defence and Security Cooperation (OPDSC) in 2017. To this end, the revised priority interventions of the Revised SADC Strategic Plan of Action on Combating Trafficking in Persons (20162019) were now encompassing capacity building and training, public education and awareness raising, victim support and witness protection, research and information sharing, coordination and regional cooperation, and harmonization and operationalization of laws (SADC 2017:5-6).

In addition to this, SADC also put in place, in collaboration with UNODOC, a SADC Regional Trafficking in Persons Data Collection System to support member states in collecting reliable and verifiable data on human trafficking at national level with a view to appreciate the nature of human trafficking, profile of traffickers and human trafficking victims, facilitate the design and implementation of programmes for combating human trafficking, and provide evidence necessary for formulating policies meant to address human trafficking crimes (SADC/UNODC 2018). 
Now, SADC has a Harmonized SADC Regional Strategic Plan on Combating Illegal Migration, Smuggling of Migrants and Trafficking in Persons (2016-2020) that provides a framework for a regional approach towards addressing and managing human trafficking in addition to strategies aimed at combating the smuggling of migrants and illegal migration. The SADC Strategic Indicative Plan for the Organ on Politics, Defence and Security Cooperation (SIPO) also acknowledges the prevalence of human trafficking in the region, which is a priority of the SIPO Public Security Sector, which is one of the five main strategic sectors of SIPO, that deals with the protection of civil society including emergency management, justice, immigration and organized crime (see SADC SIPO 2010: 17, 47, 55, 63-64). SIPO, which is an implementation framework for the SADC Protocol on Politics, Defence and Security Cooperation of 1999; aims at creating a peaceful, stable and secure environment for the attainment of socioeconomic development in the region.

In addition to the above regional frameworks for fighting human trafficking, the SADC Protocol on Gender and Development of 2008, which was amended in 2016; also provide a legal basis for addressing human trafficking. Under its preamble, the Protocol identifies human trafficking as one of the emerging threats confronting SADC member states. It commits, under Article 11, 1(d), all member states to adopt policies, legislations and programmes that protect the girl and boy child from human trafficking. Under Article 20 (5), the SADC Protocol on Gender and Development of 2008 provides a target of 2015 for member states to attain certain milestones pertaining to combating human trafficking. In the Protocol, SADC member states also commit to enact and adopt laws, by the year 2015, to prevent human trafficking and provide holistic services to reintegrated human trafficking survivors into the society; put in place mechanisms and institutions to eradicate national, regional and international human trafficking networks; put in place mechanisms for harmonized data collection and reporting on human trafficking to allow for more effective programme monitoring; establish multilateral and bilateral agreements for joint actions against human trafficking; and put in place mechanisms and campaigns for building capacity and raising awareness on human trafficking (see Article 20 (5) (a).

With a motely of instruments at its disposal to combat human trafficking, SADC member states have been engaging in the fight to combat trafficking at regional and national level with different results. What is not known is the extent 
to which anti-human trafficking strategies that have been implemented so far by SADC member states at national and regional level have produced desired results. The challenges being encountered, opportunities presented as well as future prospects in regional cooperation in combating human trafficking are not apparent hence the imperative of this research.

Successes, Challenges and Complexities in Implementing Anti-Human Trafficking Strategies in Southern Africa

In evaluating the anti-trafficking strategies that have been implemented so far by SADC member states at national and regional level, it is imperative to be guided by the main priority areas of the 10 Year SADC Strategic Plan of Action on Combating Trafficking in Persons (2009-2019), and the Harmonized SADC Regional Strategic Plan on Combating Illegal Migration, Smuggling of Migrants and Trafficking in Persons (2016-2020). The first priority is formulation of legislative and policy measures to combat human trafficking. This is also aligned to the target set by SADC in the SADC Protocol on Gender and Development of 2008. The Protocol states that by 2015 all member states should have enacted and adopted laws that prevent human trafficking and re-integrated human trafficking survivors. Almost all SADC member states have anti-trafficking laws in place as shown on Figurer 2 below.

Figure 2: Progress by SADC member states in enacting national anti-trafficking legislations

\begin{tabular}{|l|l|l|l|}
\hline \multicolumn{2}{|l|}{ Country } & Law & Year \\
\hline 1 & Angola & $\begin{array}{l}\text { Law on Criminalization of Infractions } \\
\text { Surrounding Money (criminalizes human } \\
\text { trafficking, sex trafficking and labour traf- } \\
\text { ficking) }\end{array}$ & 2014 \\
\hline 2 & Botswana & Anti-Human Trafficking Act & 2014 \\
\hline 3 & Comoros & $\begin{array}{l}\text { Law to Combat Child Labour and } \\
\text { Trafficking in Children (criminalizes child } \\
\text { trafficking) } \\
\text { Labour Code (criminalizes labour } \\
\text { trafficking) }\end{array}$ & 2014 \\
\hline
\end{tabular}




\begin{tabular}{|l|l|l|l|}
\hline \multicolumn{2}{|l|}{ Country } & Law & Year \\
\hline 4 & $\begin{array}{l}\text { Democratic } \\
\text { Republic of } \\
\text { Congo }\end{array}$ & $\begin{array}{l}\text { Sexual Violence Law (criminalizes sex } \\
\text { trafficking) } \\
\text { Child Protection Law (criminalizes child } \\
\text { trafficking) }\end{array}$ & $\begin{array}{c}2006 \\
2009\end{array}$ \\
\hline 5 & Eswatini & $\begin{array}{l}\text { People Trafficking and People Smuggling } \\
\text { (Prohibition) Act }\end{array}$ & 2009 \\
\hline 6 & Lesotho & Anti-Trafficking in Persons Act & 2011 \\
\hline 7 & Madagascar & Anti-Trafficking in Persons Law & 2014 \\
\hline 8 & Malawi & Trafficking in Persons Act & 2015 \\
\hline 9 & Mauritius & Combating of Trafficking in Persons Act & 2009 \\
\hline 10 & Mozambique & Trafficking in Persons Law & 2008 \\
\hline 11 & Namibia & Combating of Trafficking in Persons Act & 2018 \\
\hline 12 & Seychelles & Prohibition of Trafficking in Persons Act & 2014 \\
\hline 13 & South Africa & $\begin{array}{l}\text { Prevention and Combating of Trafficking in } \\
\text { Persons Act }\end{array}$ & 2013 \\
\hline 14 & Tanzania & Anti-Trafficking in Persons Act & 2008 \\
\hline 15 & Zambia & Anti-Human Trafficking Act & 2008 \\
\hline 16 & Zimbabwe & Trafficking in Persons Act & 2014 \\
\hline & & & \\
\hline
\end{tabular}

Source: Authors compilation based on national legislations databases and profiles of the different SADC countries

What can be noted therefore is that all but three SADC member countries have specific legislation to combat human trafficking in consistent with Article 11, 1(d) of the SADC Protocol on Gender and Development of 2008. Of these countries, only Namibia could not enact its anti-human trafficking legislation within the year 2015 deadline as it managed to put in place its Combating of Trafficking in Persons Act in 2018. Angola, Comoros and the Democratic Republic of Congo (DRC) are yet to have standalone legislations that deal with human trafficking. SADC has been assisting member states to enact these anti-human 
trafficking laws through the SADC Regional Political Cooperation Programme in collaboration with the UNODC and European Union (EU). Over and above the anti-human trafficking national legislations, a number of SADC member countries have formulated national policies, programmes and projects to combat human trafficking. By 2017, eight SADC countries has developed national policies and action plans to combat human trafficking (SADC 2017a:3). These include, among others, Zimbabwe (The Zimbabwe Trafficking in Persons National Plan of Action (NAPLAC) of 2016), South Africa (The Prevention and Combating of Trafficking in Persons National Policy Framework of 2019), Zambia (National Policy to Combat Human Trafficking), Malawi (National Plan of Action against Trafficking in Persons of 2017), and Seychelles (National Strategic Framework and Action Plan to Combat Trafficking in Persons).

In terms of the target to put in place mechanisms and institutions to eradicate national, regional and international human trafficking networks; SADC managed to develop and adopt the 10 Year SADC Strategic Plan of Action on Combating Trafficking in Persons (2009-2019), and subsequently revised the strategy into the Harmonized SADC Regional Strategic Plan on Combating Illegal Migration, Smuggling of Migrants and Trafficking in Persons (2016-2020). SADC also managed to develop knowledge products such as the booklet on Preventing and Combating Trafficking in Persons: Lessons from the SADC Region launched in November 2017 to share regional best practices in addressing human trafficking (SADC 2017b). In addition, pursuant to the target to put in place mechanisms for harmonized data collection and reporting on human trafficking by 2015 to allow for more effective programme monitoring; SADC has now deployed the Regional Trafficking in Persons Data Collection System and also launched the SADC Trafficking in Persons Network (SADCTIPNet) which is a regional network to combat trafficking in persons.

The other strategy has been that of training for skills enhancement and capacity building in prevention of human trafficking, training of law enforcement agencies and criminal justice officials involved in prosecution of human trafficking offenders such as prosecutors, magistrates, as well as training of all the other relevant stakeholders such as customs officers, immigration officers, and social workers. SADC has been involved in several training and capacity building initiatives through partnerships involving the SADC Secretariat and other partners such as the UNODC, IOM, and the Southern African Police 
Chiefs Cooperation Organization (SARPCCO) (see SADC 2016:4). Regional training programmes include training of key service providers in combating human trafficking in Zimbabwe (in August 2014); training of law enforcement officials in Swaziland (in early 2015); training of trainers for criminal justice practitioners in Namibia (in August 2015); training of law enforcement officers in Mozambique (in December 2015); and training of media personnel in Botswana (in June 2016) (see SADC 2017b: 9-14). Recently, SADC countries have also benefited from similar capacity building initiatives in Zambia (in 2019), and Mozambique (in September 2019) as well as Malawi where the UNODC trained police officers in investigating human trafficking cases in November 2019 (see UNODC 2019a).

SADC has also been making notable progress in implementation of prevention and public awareness raising with respect to human trafficking. Most countries continue to raise awareness through different awareness-raising initiatives on 30 July of every year after the day was proclaimed as the World Day against Trafficking in Persons, with a view to mobilize actions and cooperation in preventing human trafficking as well as protecting and prosecuting human trafficking offenders. In 2019, SADC commemorated the World Day against Trafficking in Persons under the theme 'Human Trafficking: Call your Government to action' whilst in 2018 the commemorations were under the theme 'responding to the trafficking of children and young people.' Such regional commemorations are complemented by national level commemorations, door-to-door and media campaigns, music and arts as has been the case in almost all SADC countries (see SADC 2017b:1420).

SADC has also been investing efforts to ensure close collaboration, coordination and regional cooperation as well as research and information sharing to combat human trafficking. To facilitate better coordination and regional cooperation, SADC has made progress in putting up and operationalizing structures for interstate cooperation and cross-sectoral cooperation through joint investigations, joint prosecutions, human trafficking data collection and management (SADC 2016:5). Pursuant to this, SADC member countries have forged bilateral agreements for joint actions against human trafficking, for instance through Joint Permanent Commissions on Defence and Security which provide platforms to discuss human trafficking challenges and approaches to cooperate between SADC countries. For instance, the $11^{\text {th }}$ Session of the Zimbabwe-Mozambique 
Joint Permanent Commissions on Defence and Security held on 5 March 2019 in Harare, made decisions on collaborative actions towards combating human trafficking (Munyoro and Ruwende 2019). Likewise, issues of human trafficking were also discussed at the $28^{\text {th }}$ Session of the Botswana-Namibia Joint Permanent Commissions on Defence and Security held in Gaborone from 17 to 21 February 2020; 32nd Session of the Zimbabwe-Zambia Joint Permanent Commissions on Defence and Security held in Victoria Falls on 28 March 2020 (see Tebele 2020; Murwira 2019). Other forms of bilateral and/or trilateral agreements exist, for instance The Mozambique Attorney General's Office have a bilateral Memorandum of Understanding (MoU) with South Africa, Eswatini and Zambia to cooperate on handling human trafficking cases (Trafficking in Persons Report 2019:338). In terms of research and information sharing, monitoring and evaluation, SADC has managed to conduct a baseline study and published a comprehensive report in 2016 on Trafficking in Persons in the SADC Region focusing on all the SADC countries except Comoros, DRC and Zambia.

However, whilst the above efforts and progress have been recorded by SADC, the challenge of human trafficking still persist in the region, mainly caused by poverty, insecurity, discrimination, violence and lack of implementation of effective strategies to address human trafficking in the SADC member countries (SADC 2016a). At SADC level, there are challenges relating to resources inadequacy, which have partially addressed through engaging in partnerships with organizations such as UNODC and the EU. Coordination has also been made complex given the existence of several institutions involved in addressing human trafficking. The SADC Report on Trafficking in Persons in the SADC Region concludes that the prevalence of human trafficking is resulting in serious "human rights violations, increased crime, the breakdown in social fabric, and the breakdown in human capital" whilst it also "undermines government authority as well as public health" (SADC 2016a:60).

Whilst SADC has in place the Police Chiefs Sub-Committee and the SARPCCO under the regional body's Inter-State, Defence and Security Committee of SADC's OPDSC, which is supported and complemented by the Sub-Regional Bureau of International Criminal Police Organization (INTERPOL) to detect human trafficking and curb human trafficking syndicates, among other crimes; the increased sophisticated nature of trafficking in persons, use of information communication technology is making the task complicated 
and lack of information (SADC 2019). Notwithstanding the existence of enabling instruments at SADC level that facilitate regional cooperation, such as the Protocol on Extradition, Protocol on Mutual Legal Assistance in Criminal Matters, SARPCCO Multilateral Cooperation Agreement on Combating Crime within the Region, and SARPCCO Agreement in Respect of Cooperation and Mutual Assistance in the Field of Crime Combating; regional cooperation in addressing human trafficking continue to be affected by lack of information sharing, resources inadequacy and the prevalence of corruption in the criminal justice systems of the various SADC member countries (see SADC 2016; SADC/ UNODC 2018).

The rising cases of human trafficking in several SADC member countries also suggest that the anti-trafficking strategies that are being implemented by SADC are facing challenges. In Angola, human trafficking continues to be rife as women and children are trafficked for domestic slavery and sex in South Africa, Namibia, and European countries (Trafficking in Persons Report 2019:68) whilst in Botswana, organized human trafficking syndicates traffick some women in the country and also transport women from neighbouring countries such as Zimbabwe and South Africa for sexual exploitation (Trafficking in Persons Report 2019:107). In DRC, where an estimated 150 different armed groups are involved in conflict as of February 2018, adults and children continue to be abducted and forcibly recruited into armies as soldiers, cleaners, cooks, sex slaves and spies; and it was reported that in 2018, the government in collaboration with an international organization identified and separated at least 2253 children from armed groups (Trafficking in Persons Report 2019:151-152).

A similar trend of high levels of human trafficking is reported in Malawi, where Malawian about 132 victims of sex and labour trafficking have been identified in other SADC countries namely Mozambique, South Africa, Zambia and Tanzania as well as in Kenya, Iraq, Kuwait and Saudi Arabia despite Malawi using the SADC regional data collection tool for sharing data on trafficking cases and profiles, and having in place the Trafficking in Persons Act of 2015, Anti-Trafficking in Persons Fund, human trafficking National Coordination Committee against Trafficking in Persons, district-level anti-trafficking coordination structures and other informal organizations such as the Malawi Network Against Child Trafficking (Trafficking in Persons Report 2019:305-306).

In Namibia, despite the implementation of the National Referral Mechanism 
(NRM), Standard Operating Procedures (SOPs) and the Combating of Trafficking in Persons Act of 2018 that guide the identification of, and provide protective services to, human trafficking victims; the efforts Inter-Ministerial Committee on Trafficking in Persons working in collaboration with Namibian Police Force (NamPol), the Office of the Prosecutor General, immigration officials, and other stakeholders appear inadequate as human trafficking remains widespread in Namibia, especially children exploited in forced labour and sex trafficking mostly among the vulnerable San and Zemba ethnic groups (Trafficking in Persons Report 2019:341). Other SADC countries such as South Africa are ranked high in terms of human trafficking cases despite the efforts being put by institutions such as the National Inter-Sectoral Committee on Trafficking in Persons (NICTIP), National Prosecuting Authority (NPA), South Africa Police Service (SAPS), the Department of Home Affairs (DHA), the Department of Justice (DOJ), the Department of Social Development (DSD), et cetera, in collectively implementing the Prevention and Combating of Trafficking in Persons (PACOTIP) Regulations and Prevention and Combating of Trafficking in Persons Act of 2014. The Trafficking in Persons Report (2019:426) reports;

"The [South African] government and non-government entities identified 260 victims, compared to 399 victims in 2017. Of the 260 victims identified, 201 were men, 21 were women, 34 were boys, three were girls, and one was of an unknown gender; this included 244 foreign nationals, including children from the Democratic Republic of Congo, Zimbabwe, and Mozambique and adults from Nigeria, Uganda, Rwanda, Ghana, and Thailand; 14 South Africans; and two victims of unknown nationalities. Traffickers exploited 238 victims in forced labor, 20 in sex trafficking, and two in an unknown type of trafficking. The government referred 118 victims to shelters across seven provinces; 17 victims voluntarily returned to their countries or communities; an international organization assisted in repatriating victims".

This has also been the case in Tanzania, Zimbabwe, Zambia and other SADC member countries. In light of the prevalent cases of human trafficking in the region, the SADC Regional Trafficking in Persons Data Collection System as well as other human trafficking reports focusing on the region presents opportunities 
for the identification of policy, legislative, institutional and capacity gaps and constraints which SADC can better address through reviewing its strategies and interventions at both regional and national level. The persistent challenges are an opportunity to intensify collaborations and share best practices in identifying the root causes of human trafficking, mapping human trafficking flows, identifying human trafficking syndicates, protection of groups vulnerable to human trafficking, strategies used by human traffickers, cooperation in prosecution and extradition of human trafficking offenders, management of human trafficking victims, and building capacities of institutions working on combating human trafficking.

\section{Conclusion and Recommendations}

Having evaluated the anti-trafficking strategies that have been implemented so far by SADC member states at national and regional level, it has been noted the whilst various strategies in place have managed to foster cooperation in addressing human trafficking, member states continue to face the scourge of human trafficking for various reasons. The effectiveness of the strategies and instruments for combating human trafficking in SADC, namely, the 10 Year SADC Strategic Plan of Action on Combating Trafficking in Persons, especially Women and Children (2009-2019), the Revised Strategic Plan of Action on Combating Trafficking in Persons, especially Women and Children (20162019) and the SADC Protocol on Gender and Development of 2008; have been compromised by the evolving complexity of strategies being used by human trafficking syndicates, shortcomings in institutional capacity, technology, resources and absence of specific human trafficking legislative framework. As discussed above, there several institutions at regional and national level in SADC that deal with human trafficking which poses coordination challenges.

It is recommended that the regional body strengthen its coordination mechanism to allow for better cooperation. More bilateral and trilateral agreements between and among contiguous SADC countries may assist to foster better cooperation in fighting human trafficking in the region whilst continuous capacity building initiatives are critical in enhancing the efficacy of antitrafficking institutions. The challenges faced in implementing anti-trafficking strategies in SADC present opportunities to review approaches for more effective 
regional cooperation, collaboration and networking. There is need to raise more awareness, and forge partnerships to address and bridge the capacity deficiencies so as to cope with the rising cases of human trafficking. 


\section{References}

Abdullah, FM (2019), "Legal and Ethical Aspects beyond Commercial Surrogacy: Modern Form of Human Trafficking, Journal of Legal, Ethical and Regulatory Issues, Vol 22, No 1, pp 1-6.

African Development Bank (2019), "Regional Integration Strategic Framework

- Revised”. 25 January 2019. AfDB, RDRI Department. (Available at: https:// www.afdb.org/en/documents/document/regional-integration-strategicframework-revised-107459, accessed 4 January 2020).

Anderson, B and JO Davidson (2003), "Is Trafficking in Human Beings Demand Driven? A Multi-Country Pilot Study", Geneva: International Organization for Migration.

Busch-Armendariz, N; Nsonwu, M and L Cook Heffron (2009), "Understanding Human Trafficking: Development of Typologies of Traffickers PHASE II”. Annual Interdisciplinary Conference on Human Trafficking, University of Nebraska, Nebraska.

Costa CB, McCoy KT, Early GJ and CM Deckers (2019), "Evidence-Based Care of the Human Trafficking Patient”, Nursing Clinics, Vol 54, No 4, pp 569-584.

Economic Community for West African States (2019), "ECOWAS Reviews Strategy to Curb Trafficking in Persons in the Region”. (Available at: https:// www.ecowas.int/ecowas-reviews-strategy-to-curb-trafficking-in-persons-inthe-region/, accessed 18 December 2019).

Ewi, M and K Aning (2006), "Assessing the Role of the African Union in Preventing and Combating Terrorism in Africa", African Security Review, Vol 15, No 3, pp 32-46.

Fang, S, Nguyen, P, Coverdale, J and M Gordon (2019), "What are the Human Trafficking Policies of Professional Medical Organizations?” Journal of Human Trafficking, pp 1-8. (Available at: https://fmwc.ca/wp-content/ uploads/2019/12/2019-Human-Trafficking-Policies-of-US-Medical-Orgs.pdf, accessed 18 December 2019).

Farrell, A, Bouché, V and D, Wolfe (2019), "Assessing the Impact of State Human Trafficking Legislation on Criminal Justice System Outcomes", Law and Policy, Vol 41, No 2, pp 174-197.

Gordon, S (2009), "Regionalism and Cross-Border Cooperation against Crime and Terrorism in the Asia-Pacific", Security Challenges, Vol 5, No 4, pp 75-102 
International Organization for Migration (2018), "Human Trafficking Global Database, 2017. (Available at: https://migrationdataportal.org/sites/default/ files/2017-12/Exploitation\%20types_05.12.2017-01_0.png, accessed 2 December 2019).

Jesperson, S, Henriksen, R, Barry, AM and M Jones (2019), Human Trafficking: An Organised Crime? London: Hurst \& Company Ltd.

Kaye, J, Millar, H and T O'Doherty (2020), "Exploring Human Rights in the Context of Enforcement-Based Anti-trafficking in Persons Responses", in Winterdyk, J and J Jones (eds), The Palgrave International Handbook of Human Trafficking. London: Palgrave MacMillan, pp 601-621.

Markovic, DM; Dostic, S and Z Radojkovic (2019), "Criminal-Law and Criminalistics Aspects of Distinguishing People Smuggling from Human Trafficking”, International Journal of Economics and Law, Vol 9, No 24, pp 93-102. Masabo, CJ; Wama, M and TP Mlyansi (2014), “The Role of Regional Integration in Fighting Crime and Terrorism: The Case of the Africa Union's (AU's) Initiatives, 1999-2014". Peace and Conflict Monitor, University of Peace. (Available at: http://www.monitor.upeace.org/innerpg.cfm?id_article=1066, accessed 7 January 2020).

Mau, S; Gülzau, F; Laube, L and N Zaun (2015), "The Global Mobility Divide: How Visa Policies have Evolved over Time”, Journal of Ethnic and Migration Studies, Vol 41, No 8, pp 1192-1213.

McKenzie, M (2019), "Securitising Transnational Crime: the Political Drivers of Police Cooperation between Australia and Indonesia”, Policing and Society, Vol 29, No 3, pp 333-348.

Munyoro F and V Maphosa (2019), "Zim/Moza Joint Commission Underscores Need to Arrest Cross-border Crimes”. The Herald Newspaper, 7 March 2019. (Available at: https:/www.chronicle.co.zw/zimmoza-joint-commissionunderscores-need-to-arrest-cross-border-crimes/, accessed 14 February 2020).

Murray, A and L Smith (2019), "Implementing Evidence-Based Care for Women Who Have Experienced Human Trafficking”, Nursing for Women's Health, Vol 23, No 2, pp 98-104.

Murwira, Z (2019), “Zim, Zambia JPC Raps US over Sanctions. The Herald Newspaper, 29 March 2019”. (Available at: https://www.herald.co.zw/zimzambia-jpc-raps-us-over-sanctions/, accessed 14 February 2020). 
Sinha, R; Tashakor, E and C Pinto (2019), "Identifying Victims of Human Trafficking in Central Pennsylvania: A Survey of Health-Care Professionals and Students", Journal of Human Trafficking, Vol 5, No 2, pp 165-175.

Skilbrei, ML (2019), "Criminological Perspectives on Human Trafficking", in Valsamis, M; Saskia, H and A Moiseienko (eds), Research Handbook on Transnational Crime. Cheltenham/Camberley: Edward Elgar Publishing, pp 21-37.

Smith, CJ and K Kangaspunta (2012), "Defining Human Trafficking and its Nuances in a Cultural Context”, in Winterdyk. J., B. Perrin and P. Reichel (eds), Human Trafficking: Exploring the International Nature, Concerns, and Complexities, New York: CRC Press, pp 19-38.

Southern African Development Community (2008), SADC Protocol on Gender and Development of 2008. (Available at: https:/www.sadc.int/ files/8713/5292/8364/Protocol_on_Gender_and_Development_2008.pdf, accessed 24 January 2020)

Southern African Development Community (2009), "10 Year SADC Strategic Plan of Action on Combating Trafficking in Persons, especially Women and Children (2009-2019)", SADC Secretariat: Gaborone.

Southern African Development Community (2010), "Revised Edition Strategic Indicative Plan for the Organ on Politics, Defence and Security Cooperation”. Maputo, 5 August 2010. (Available at: https://www.sadc.int/ files/3213/7951/6823/03514_SADC_SIPO_English.pdf, accessed 22 January 2020).

Southern African Development Community (2016), "Trafficking in Persons in the SADC Region”. Policy Brief, August 2016. (Available at: https://www.sadc. int/files/8414/7505/0081/SADC_TIP_Policy_Brief_-_English_FINAL.pdf, accessed 31 January 2020).

Southern African Development Community (2016a), "Trafficking in Persons in the SADC Region: A Baseline Report”. (Available at: https:/www.sadc.int/ files/3514/7505/0085/SADC_Baseline_Report_Low_Resolution.pdf, accessed 19 February 2020).

Southern African Development Community (2017), "Revised SADC Strategic Plan of Action on Combating Trafficking in Persons, especially Women and Children (2016-2019)". SADC Secretariat: Gaborone, (Available at: https:// www.unodc.org/documents/southernafrica//Stories/EN_-_TIP_Statistical_ Report.pdf, accessed 16 January 2020). 
Southern African Development Community (2017a), "SADC Launches Trafficking in Persons Lessons Booklet”, 1 November 2017, (Available at: https://www.sadc.int/news-events/news/sadc-launches-trafficking-personslessons-booklet/, accessed 28 January 2020).

Southern African Development Community (2017b),"Preventing and Combating Trafficking in Persons: Lessons from the SADC Region”. SADC Secretariat, Gaborone, (Available at: https://www.sadc.int/files/1115/0953/7902/EN_TIP_ Lessons.pdf, accessed 4 February 2020).

Southern African Development Community (2019), "SADC/SARPCCO Chiefs of Police Sub-Committee of the Inter-State Defence and Security Committee Annual General Meeting held in Lusaka, Zambia”, June. (Available at: https:// www.sadc.int/news-events/news/sadcsarpcco-chiefs-police-sub-committeeinter-state-defence-and-security-committee-annual-general-meeting-heldlusaka-zambia/, accessed 21 February 2020).

Southern African Development Community/United Nations Office on Drugs and Crime (2018), "Trafficking in Persons in the SADC Region: A Statistical Report (2014-2016)”. SADC Trafficking in Persons Network (SADCTIPNet), (Available at: https://www.unodc.org/documents/southernafrica//Stories/ EN_-_TIP_Statistical_Report.pdf, accessed 12 January 2020).

Stevens, S; Acker, S; Green, K; Swales, S; Fulmer, HM; Fortinsky, R and PK Nicholas (2019), "Understanding the Mental Health Impact of Human Trafficking”, Journal of the American Association of Nurse Practitioners, Vol 31, No 12, pp 699-704.

Sutherland, ME (2019), "Breaking the Chains: Human Trafficking and Health Care Providers”, Missouri Medicine, Vol 116, No 6, pp 454-456.

Tebele, M (2020), "Botswana, Namibia Push Ahead with Ports Free Entry”. The Southern Times, 8 February 2020. (Available at: https://southerntimesafrica. com/site/news/botswana-namibia-push-ahead-with-ports-free-entry, accessed 14 February 2020).

United Nations (2000a), "Protocol to Prevent, Supress and Punish Trafficking in Persons, especially Women and Children of 2000 Supplementing the United Nations Convention Against Transnational Organized Crime”. Available at: https://www.unodc.org/documents/treaties/Special/2000_Protocol_to_ Prevent_2C_Suppress_and_Punish_Trafficking_in_Persons.pdf, accessed 19 December 2019).

United Nations (2000b), "Protocol Against the Smuggling of Migrants by 
Land, Sea and Air Supplementing the United Nations Convention Against Transnational Organized Crime”. (Available at:https://www.unodc.org/ documents/middleeastandnorthafrica/smuggling-migrants/SoM_Protocol_ English.pdf, accessed 19 December 2019).

United Nations (2020), "Sustainable Development Goal 8”. (Available at: https:// sustainabledevelopment.un.org/sdg8, accessed 10 December 2019).

United Nations (2020), “United Nations Treaty Collection”, (Available at: https:// treaties.un.org/Pages/ViewDetails.aspx?src=IND\&mtdsg_no=XVIII-12a\&chapter=18\&lang=en, accessed 19 January 2020).

United Nations Office on Drugs and Crime (2018), "Global Report on Trafficking in Persons 2018”. UNODC (United Nations Publication, Sales No. E.19. IV.2). (Available at: https://www.unodc.org/documents/data-and-analysis/ glotip/2018/GLOTiP_2018_BOOK_web_small.pdf, accessed 10 December 2019).

United Nations Office on Drugs and Crime (2019), "Malawi Police Officers Trained by UNODC Rescue Trafficked Nepali Nationals”. (Available at: https:// www.unodc.org/unodc/en/frontpage/2019/November/malawi-police-officerstrained-by-unodc-rescue-trafficked-nepali-nationals.html?ref=fs1, accessed 8 February 2020).

United Nations Office on Drugs and Crime (2019a), "World Day Against Trafficking in Persons”, 30 July 2020, (Available at: https:/www.un.org/en/ events/humantrafficking/, accessed 10 December 2019).

United States of America Department of State (2019), "Trafficking in Persons Report”, June. (Available at: https://www.state.gov/wp-content/ uploads/2019/06/2019-Trafficking-in-Persons-Report.pdf, accessed 28 February 2020).

Vanwesenbeeck, I (2019), “The Making of "The Trafficking Problem”, Archives of Sexual Behavior, Vol 48, No 7, pp 1961-1967.

Wade, ML (2020), "Combatting Trafficking in Human Beings: A Step on the Road to Global Justice?”, in Winterdyk, J and J Jones (eds), The Palgrave International Handbook of Human Trafficking. London: Palgrave MacMillan, pp 1183-1203.

Winterdyk, J (2020), "Explaining Human Trafficking: Modern Day-Slavery”, in Winterdyk, J and J Jones (eds), The Palgrave International Handbook of Human Trafficking. London: Palgrave MacMillan, pp 1257-1274. 
